\title{
Social Exclusion, Self-Forgiveness, Mindfulness, and Internet Addiction in College Students: a Moderated Mediation Approach
}

\author{
Gökmen Arslan $^{1}$ (D) Muhammet Coşkun ${ }^{2}$
}

Accepted: 22 February 2021 / Published online: 8 March 2021

(C) The Author(s), under exclusive licence to Springer Science+Business Media, LLC, part of Springer Nature 2021

\begin{abstract}
Internet addiction is a growingly prevalent behavioral addiction that causes numerous psychosocial problems. Investigating the causes and consequences of Internet addiction is fundamental to comprehend and prevent it. Therefore, the current study provided protective and promotive factors for undesired effects of social exclusion on Internet addiction. The study examined a moderated mediation model to test whether mindfulness moderated the mediating role of self-forgiveness in the association between social exclusion and Internet addiction among young adults. The participants of the present study included 358 undergraduate students attending a state university in Turkey. They ranged in age from 20 to 28 years $(M=21.89, S D=1.95)$. The participants comprised $206(57.5 \%)$ female and $152(42.5 \%)$ male college young adults. Overall, the study findings indicated that selfforgiveness mediated the relationship between social exclusion and Internet addiction, and mindfulness moderated the mediating role of self-forgiveness in this association. Contending with negative outcomes of social exclusion and Internet addiction, and mitigating and buffering roles of self-forgiveness and mindfulness provide important implications to design prevention and intervention services for reducing Internet-related addictive behaviors.
\end{abstract}

Keywords Social exclusion · Forgiveness · Mindfulness · Internet addiction · College students

"No person is an island" (Donne 1975). This famous quote makes it clear that we are social creatures desiring to form and maintain positive, coherent, and meaningful relationships with others. As self-determination theory (Deci and Ryan 1985) and need-to-belong theory (Baumeister and Leary 1995) emphasize, being related or belongingness is a basic and universal psychological need for the human being, and a number of empirical studies have

Gökmen Arslan

garslan@mehmetakif.edu.tr

1 Department of Psychological Counseling and Guidance, Mehmet Akif Ersoy University, Burdur, Turkey

2 Department of Psychological Counseling and Guidance, Kafkas University, Kars, Turkey 
proved the vitality of belongingness in determining psychological well-being and functioning (Arslan 2018b; Deci and Ryan 2008) with potential risks for psychological and physical disorders (Arslan 2020; Baumeister 2012). Within this scope, social exclusion, being rejected and ignored by social groups (Williams 2007a), is a painful experience that frustrates the basic need to belong and causes social pain (Hartgerink et al. 2015; Riva et al. 2011). Social exclusion has been associated with meaninglessness (Stillman et al. 2009), mental health problems (Arslan 2018a), sense of dehumanization (Bastian and Haslam 2010), reduced happiness (Sjåstad et al. 2020), increased depression and aggression (Arslan 2021; Gilman et al. 2013; Florez et al. 2020), academic deficiencies (Arslan 2016), negative affect (Stanley et al. 2020), and so on. Compared to inclusion, socially excluded individuals experience cognitive impairments (Buelow and Wirth 2017), and difficulties arise in their self-regulation ability (Oaten et al. 2008). Therefore, they go for riskier decision-makings that result in destructive and problematic behaviors (Arslan et al. 2021; Buelow and Wirth 2017; Duru et al. 2016; Peake et al. 2013) including alcohol addiction (Bacon et al. 2015) and unhealthy behaviors (Twenge et al. 2002).

Social exclusion may also lead to another self-defeating behavior called Internet addiction that is related to serious psychological problems especially for the age range between adolescence and adulthood (Bozoglan and Demirer 2015; Koç 2017). Deficient selfregulation is an influential factor behind Internet addiction and unregulated Internet usage (Caplan 2010; LaRose et al. 2003; Tokunaga 2015). Moreover, socially excluded people are more prone to isolate themselves from others to avoid any possibility of re-experiencing a social exclusion scenario (Molden et al. 2009; Pfundmair et al. 2015). To escape the social world, these individuals may prefer a virtual world where they can feel safe and avoid suffering from social anxiety and interpersonal problems, although they may feel loneliness (Caplan 2007). Therefore, social exclusion seems to lead people to seek more solitude (Ren et al. 2016), and solitude seeking was already found to give rise to Internet usage (Wang et al. 2012). Moreover, it is also known that loneliness and excessive Internet usage mutually feed each other (Özdemir et al. 2014; Yao and Zhong 2014).

Considering all mentioned above, exploring the relationship between social exclusion and Internet addiction, two detrimental factors for human functioning, it is important to design interventions for reducing addictive behaviors among young adults. Although several indicators (e.g., impaired self-regulation, solitude seeking, avoiding social interactions) point out the association between social exclusion and Internet addiction, there are limited research findings on it with contradictory results. For example, a positive relationship between social exclusion and Internet addiction was revealed by some early research (Lim 2019; Poon 2018). Similarly, Tas and Öztosun (2018) concluded the positive predictor role of social exclusion on Internet addiction in a Turkish sample. On the other hand, in another study again with a Turkish sample, no significant association between these two variables was reported (Bagir et al. 2020). To this end, the present study aims to shed light on the gap and controversy regarding the association between social exclusion and Internet addiction. Furthermore, this study also attempts to discover the mediating and moderating roles of self-forgiveness and mindfulness, two mechanisms that may mitigate and moderate the relationship between social exclusion and Internet addiction. 


\section{Self-Forgiveness and Mindfulness}

Self-forgiveness is a process of emotion regulation that involves acknowledging responsibility for behavior, acceptance of negative feelings, and gradual replacement of selfdirected thoughts, emotions, and behavior (Hall and Fincham 2005; Wohl et al. 2008). Socially excluded individuals are likely to feel negative emotions of sadness, frustration, anger, and stress; and they have a tendency to attribute blame to the self with low selfappraisal (Williams 2007a, p14). As Hall and Fincham (2005) stated, self-directed negative feelings and their psychological and physical effects might be restored through self-forgiveness. Therefore, self-forgiveness may diminish guilt, self-blame, and selfresentment, and may foster increased self-worth and self-compassion (Wohl and McLaughlin 2014). Forgiveness itself helps the replacement of negative emotions with positive ones (Hall and Fincham 2005). Thus, forgiveness may also affect the way people react to the impacts of social exclusion. To illustrate, Zhang et al. (2019) reported that forgiveness decreased the negative impact of social exclusion on anger and aggression. Likewise, forgiveness was found to be an effective coping strategy against the negative impacts of bullying, which is a relational kind of social exclusion (Egan and Todorov 2009). In addition, the benefits of these coping strategies may be generalized to people with Internet addiction problems. The functional role of self-forgiveness in addictive problems was already determined by several empirical findings (Gueta 2013; Hook et al. 2015; Webb et al. 2011), and the same functionality was also captured in Internet addiction (Arslan 2017). Nevertheless, to the best of the authors' knowledge, no study has tested the social exclusion and self-forgiveness interaction despite the signs as stated above.

Mindfulness is another potential coping strategy that can reduce aggression and social anxiety while increasing self-worth and well-being (Heppner et al. 2008; Lundwall et al. 2019; Rasmussen and Pidgeon 2011; Tanhan and Francisco 2019; Tanhan and Strack 2020). Mindfulness has its root in great Eastern and Western religious or spiritual traditions, and mindfulness can take different forms and names in different traditions (e.g., mindful eating, praying, muraqaba; Tanhan 2019). Mindfulness is a nonjudgmental acceptance of a person's experience with a state of awareness with opening space even for distressing and maladaptive thoughts and feelings (Hayes and Feldman 2004; Tanhan 2019). Mindfulness has positive effects on psychological health such as better well-being, better emotional reactivity, and enhanced behavioral regulation (Keng et al. 2011; Tanhan 2020). Previous research has supported the idea that mindfulness might be a strong mechanism to cope with the self-defeating effects of social exclusion. Jahanzeb et al. (2020) discovered the detrimental effect of social exclusion on job performance through acquiescence silence, but higher mindfulness of individuals buffered the effect of exclusion on acquiescence silence. Christensen-Salem et al. (2020) also detected the negative relationship between mindfulness and social exclusion. Mindfulness promotes behavioral regulation ability (Keng et al. 2011), which is the main problem behind Internet addiction (Caplan 2010; LaRose et al. 2003; Tokunaga 2015). Thereby, mindfulness might prevent Internet addiction. Past research supported this hypothesis that mindfulness had a positive impact on excessive Internet use and other problematic behaviors like pathological gambling (Calvete et al. 2017; Gámez-Guadix and Calvete 2016; Riley 2014). Moreover, Arslan (2017) showed that mindfulness was negatively associated with Internet addiction and suggested that both forgiveness and 
mindfulness should be used as treatment strategies against Internet addiction. Overall, in light of related literature, forgiveness and mindfulness may play alleviating roles in the association between social exclusion and Internet addiction, and mindfulness is expected to buffer the effect of social exclusion on Internet addiction.

\section{The Current Study}

The recent study aims to investigate the relationship between social exclusion and Internet addiction by considering the mediating and moderating roles of selfforgiveness and mindfulness. Social exclusion is defined as "the kiss of social death" by Williams (2007b) with vital negative outcomes, as explained above. Internet addiction is another toxic problem that brings about severe psychological problems. Exploring the factors behind Internet addiction is crucial to understand, prevent, and intervene against it (Young et al. 2011). Since social exclusion causes deficient behavioral regulation, social anxiety, solitude seeking, and other negative effects that seem to provide a basis for Internet addiction, a positive association is expected between social exclusion and Internet addiction. Moreover, rather than just pointing out the causes of Internet addiction, self-forgiveness and mindfulness as two potential mitigating factors are going to be presented. By doing so, a model linking the negative and positive impacts of important variables for human functioning can be drawn. We tested the following hypotheses $\left(H_{1}\right)$ to examine whether self-forgiveness mediated the association between social exclusion and Internet addiction and $\left(\mathrm{H}_{2}\right)$ whether mindfulness moderated the mediating effect of self-forgiveness on the association between social exclusion and Internet addiction, as shown in Fig. 1.

\section{Method}

\section{Participants}

The participants of the present study included 358 undergraduate students attending a state university in an urban city in Turkey. They ranged in age from 20 to 28 years $(M=$ 21.89, $S D=1.95)$. The participants comprised $206(57.5 \%)$ female and $152(42.5 \%)$ male college young adults. They also reported their socioeconomic statuses (SES) as follows:

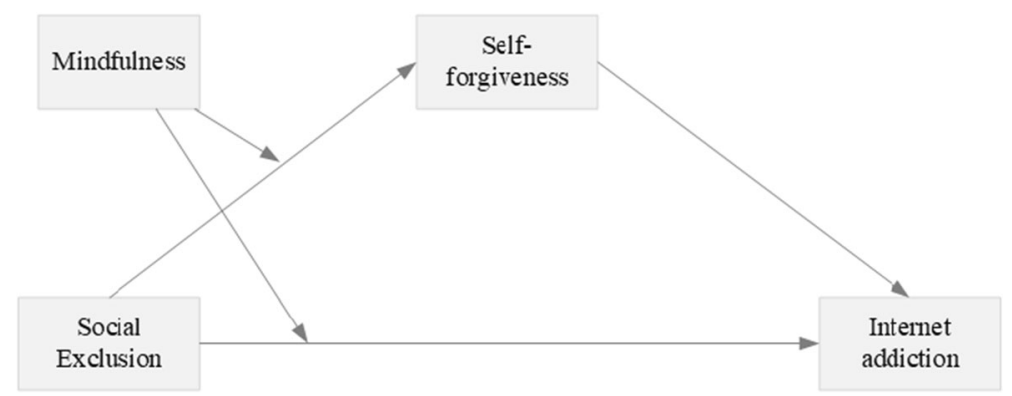

Fig. 1 The conceptual model 
low $\mathrm{SES}=9.2 \%$, moderate $\mathrm{SES}=62.8 \%$, and high $\mathrm{SES}=27.7 \%$. Before starting the data collection, a consent form was presented that ensured them that their responses would be used only anonymously for study purposes based on their voluntary participation. A paper-and-pencil survey was created using demographic items and study measurement tools, and the survey was administered to the students who had volunteered to participate.

\section{Measures}

Social Exclusion Scale (SES) The SES, a subscale of the General Belongingness Scale (GBS; Malone et al. 2012), was used to measure individuals' perception of social exclusion. The SES includes six items scored from strongly disagree (1) to strongly agree (7; e.g., "Friends and family do not involve me in their plans"). Previous studies reported the scale had adequate internal reliability estimates with Turkish young adults (Duru 2015). Findings from this study indicated the internal reliability estimate of SES was adequate $(\alpha=.85)$.

Internet Addiction Test (IAT) The IAT was used to assess the addictive Internet use of college students (Young 1998). The IAT is a 20-item self-report instrument (e.g., "How often do you find that you stay online longer than you intended to?") and the scale's items were responded to using a 5-point Likert scale ranging from does not apply (1) to always applies (5). The scale provided adequate internal reliability estimates for the Turkish sample (Boysan et al. 2017). In the present study, the internal reliability estimate of the scale was adequate $(\alpha=.89)$.

Self-Forgiveness Scale (SFS) The SFS, a subscale of the Heartland Forgiveness Scale (HFS; Thompson et al. 2005), was used to measure an individual's self-forgiveness level (e.g., "Although I feel bad at first when I mess up, over time I can give myself some slack"). The scale includes six items scoring based on a 7-point Likert scale ranging from almost always false more than true (1) to almost always true for me (7). Past research demonstrated that the scale had an adequate internal reliability estimate with a Turkish sample (Bugay and Demir 2010). The internal reliability estimate of the scale with the present sample was adequate $(\alpha=.89)$.

Mindfulness Scale (MS) The MS, a subscale of the Compassion Scale (CS; Pommier 2011), was used to measure young adults' mindfulness levels. The MS includes four items (e.g., "I notice when people are upset, even if they don't say anything."), and all items are scored on a 5-point Likert scale ranging between almost never (1) and almost always (5). Previous research showed that the scale demonstrated an adequate internal reliability estimate with a Turkish sample $(\alpha=.85$; Akdeniz and Deniz 2016). In the present study, the internal reliability estimate of the scale was adequate $(\alpha=.67)$.

\section{Data Analyses}

As the first phase of the data analyses, descriptive statistics and correlation analyses for the variables of the study were conducted. The assumption of normality was checked using the scores of kurtosis and skewness, and their values $<|1|$ are reported as acceptable for a normal distribution (Field 2009). Pearson product-moment analysis was next performed to examine 
the relationships between the study variables. As the second phase of the data analyses, a moderated mediation model was employed to test whether mindfulness moderated the mediating role of self-forgiveness in the association between social exclusion and Internet addiction using the PROCESS macro version 3.5 (Model 8) for SPSS (Hayes 2018). The significance of indirect effects in the moderated mediation model was examined using the bootstrapping method with 5000 resamples to estimate the 95\% confidence intervals (Hayes 2018; Preacher and Hayes 2008). All study analyses were employed using SPSS version 25.

\section{Results}

Descriptive statistics results showed that skewness and kurtosis scores were between -.81 and .57 , indicating that all study variables were relatively normally distributed (kurtosis and skewness scores $<|1|)$. Furthermore, correlation analysis showed that social exclusion had significant and negative correlations with self-forgiveness and mindfulness, but was positively correlated with Internet addiction. Internet addiction was also negatively and significantly associated with self-forgiveness and mindfulness. There was a positive and significant relationship between self-forgiveness and mindfulness. Descriptive statistics, correlation results, and internal reliability estimates for the study variables are shown in Table 1.

After examining the descriptive statistics, the moderated mediation model was performed to explore whether mindfulness moderated the mediating effect of self-forgiveness in the relationship between social exclusion and Internet addiction. Results from the moderated mediation analysis revealed that self-forgiveness was significantly predicted by social exclusion and mindfulness, and the model accounted for $12 \%$ of the variance in self-forgiveness. Mindfulness also significantly moderated the predictive effect of social exclusion on the selfforgiveness of young people (interaction effect $b=-.02, p<.001 ; R^{2}$ change $=.03$ ). The simple slope also indicated that the indirect effect of social exclusion on self-forgiveness was observed when mindfulness was high $(+1 S D)$ and moderate yet not when mindfulness was low $(-1 S D)$, as seen in Fig. 2.

The results of the study further indicated that Internet addiction was significantly predicted by social exclusion, self-forgiveness, and mindfulness. Mindfulness moderated the effect of social exclusion (interaction effect $b=.04, p<.05 ; R^{2}$ change $=.01$ ) on Internet addiction among young people. All variables together explained $18 \%$ of the variance in Internet addiction. The simple slope also revealed that the indirect effect of social exclusion on Internet addiction was observed when mindfulness was low (-1SD) and moderate, but not when mindfulness was high $(+1 S D)$, as seen in Fig. 2. Taken together, the study results indicated

Table 1 Descriptive statistics and correlations between variables

\begin{tabular}{|c|c|c|c|c|c|c|c|c|c|c|c|}
\hline \multirow[t]{2}{*}{ Scale } & \multicolumn{7}{|c|}{ Descriptive statistics } & \multicolumn{4}{|c|}{ Correlation coefficients $(r)$} \\
\hline & $\alpha$ & Min. & Max. & $M$ & $S D$ & Skew & Kurt & 1. & 2. & 3. & 4. \\
\hline 1. SES & .85 & 6 & 42 & 18.13 & 10.14 & .49 & -.81 & - & & & \\
\hline 2. SFS & .89 & 10 & 42 & 26.44 & 5.04 & .30 & .45 & $-.24 * *$ & - & & \\
\hline 3. MS & .67 & 4 & 20 & 14.28 & 3.81 & -.34 & -.65 & $-.42 * *$ & $.27 * *$ & - & \\
\hline 4. IAS & .89 & 23 & 95 & 57.83 & 12.79 & .57 & .12 & $.35 * *$ & $-.24 * *$ & $-.31 * *$ & - \\
\hline
\end{tabular}

*** $p<.001$. Skew, skewness; Kurt, kurtosis; SES, social exclusion; SFS, self-forgiveness; MS, mindfulness; IAS, Internet addiction; Min and Max, minimum and maximum scores; $\alpha$, Internal reliability coefficient 

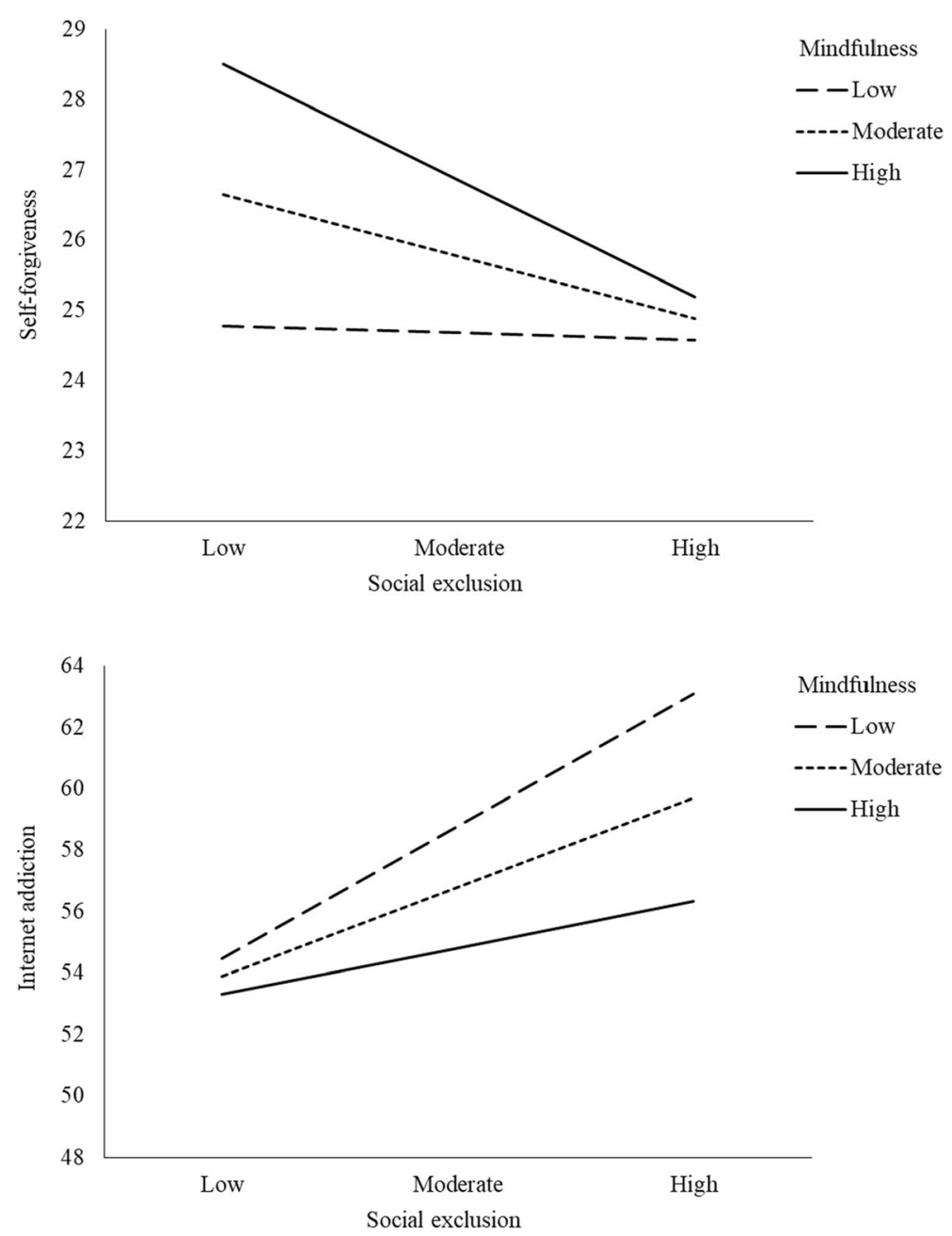

Fig. 2 Moderating effects of mindfulness

that self-forgiveness mediated the impacts of social exclusion on Internet addiction, and mindfulness had a protective role on forgiveness and addictive behaviors in the face of adverse impacts of social exclusion among Turkish young people (Table 2).

\section{Discussion}

Internet addiction is a growingly prevalent behavioral addiction (Pezoa-Jares et al. 2012) that causes numerous psychological problems (Arslan et al. 2021; Bozoglan and Demirer 2015). For example, in a recent study conducted during the COVID-19 pandemic, Tanhan (2020) reported that about $5 \%(N=127)$ of the college students as the participants reported psychopathology including "online addiction disorders" as one of the most important concerns for their mental health. Aligning with our results, the participants reported mindfulness (e.g., being present at the moment, 33\%) as one of the most important facilitators for their mental health 
Table 2 Unstandardized coefficients for the moderated mediation model

\begin{tabular}{|c|c|c|c|c|c|c|c|c|}
\hline \multirow[b]{2}{*}{ Antecedent } & \multicolumn{7}{|c|}{ Consequent } & $Y$ (Internet addiction) \\
\hline & Coeff. & $S E$ & $t$ & $p$ & Coeff. & $S E$ & $t$ & $p$ \\
\hline$X$ (social exclusion) & -.09 & .03 & -3.17 & .001 & .29 & .07 & 4.19 & $<.001$ \\
\hline$M$ (self-forgiveness) & - & - & - & - & -.39 & 13 & -2.98 & .003 \\
\hline$W$ (mindfulness) & .28 & .07 & 3.93 & $<.001$ & -.51 & 18 & -2.85 & .004 \\
\hline$X \times W$ & -.02 & .01 & -3.24 & $<.001$ & -.04 & .02 & -2.34 & .020 \\
\hline \multirow[t]{2}{*}{ Constant } & 25.76 & .27 & 95.39 & $<.001$ & 66.93 & 3.42 & 19.55 & $<.001$ \\
\hline & \multicolumn{4}{|c|}{$R^{2}=.12 ; R^{2}$ change $=.03$} & \multicolumn{4}{|c|}{$\begin{array}{l}R^{2}=.18 ; R^{2} \text { change }=.01 \\
F=19.54 ; p<.001\end{array}$} \\
\hline \multicolumn{9}{|c|}{ Conditional indirect effect of social exclusion on Internet addiction through self-forgiveness } \\
\hline Mindfulness & Effect & & Boot $S E$ & & Boot L & $95 \%$ & & Boot UL 95\% CI \\
\hline$-1 S D(-3.80)$ & .01 & & .01 & & -.02 & & & .03 \\
\hline$M(.00)$ & .03 & & .02 & & .01 & & & .07 \\
\hline$+1 S D(3.80)$ & .06 & & .03 & & .02 & & & .12 \\
\hline
\end{tabular}

$S E$, standard error; Coeff, unstandardized coefficient; $X$, independent variable; $M$, mediator variables; $Y$, outcomes or dependent variables. Bootstrap sample size $=5000$

well-being during the COVID-19 home confinement (Tanhan 2020). Based on all these, investigating the causes and consequences of Internet addiction and its relationship with other variables is fundamental to comprehend, prevent, and intervene in the addiction (Young et al. 2011). Therefore, as a predictive factor, we tested the concept of social exclusion, which restrains individuals from satisfying the basic need of belongingness and creates devastating physical and psychological consequences for human functioning (Arslan 2018c; Baumeister 2012; Fung et al. 2016). Moreover, the current study has also provided buffering factors for undesired effects of social exclusion on Internet addiction. All in all, the present study examined a moderated mediation model to test whether mindfulness moderated the mediating role of self-forgiveness in the association between social exclusion and Internet addiction. Overall findings showed that social exclusion significantly predicted increased Internet addiction, and self-forgiveness mediated this effect with the moderating role of mindfulness. In line with our expectations, forgiveness toward the self and being mindful mitigated and moderated the positive association between two hazardous phenomena, social exclusion and Internet addiction.

First, the results showed that social exclusion positively predicted Internet addiction, as also captured by a limited number of past research (Lim 2019; Poon 2018). However, in the Turkish sample, while Tas and Öztosun (2018) came up with a supportive finding, another early research did not report a significant relationship between social exclusion and Internet addiction (Bagir et al. 2020). The current study is thought to shed light on this controversy both in national and broader contexts. Thwarted fulfillment of being related is responsible for countless problems as clearly discussed earlier above. Being excluded leads people to experience some deprivation in cognitive reasoning and self-regulation (Buelow and Wirth 2017; Oaten et al. 2008), and these are some main impairments that lie behind Internet addiction (Tokunaga 2015). Furthermore, increased social anxiety by social exclusion also pushes victims to stay in loneliness to refrain from re-experiencing an exclusion scenario (Caplan 2007), and loneliness itself contributes to Internet addiction (Wang et al. 2012; Yao and Zhong 2014).

Additionally, social exclusion negatively predicted both self-forgiveness and mindfulness as expected. And no research has directly examined the relationship of self-forgiveness with 
social exclusion. However, past literature emphasized that self-forgiveness helped the replacement of the self-directed negativity with better self-worth and self-compassion (Hall and Fincham 2005; Wohl and McLaughlin 2014). It is also known that enhanced self-worth and self-compassion weakened the threatening outcomes of social exclusion (Jiang and Chen 2020). The negative association between social exclusion and mindfulness was also in line with early findings in the related literature (Christensen-Salem et al. 2020; Jahanzeb et al. 2020). Similar to self-forgiveness, being mindful enables people to restore dysfunctional thoughts and feelings with functional ones that contribute to psychological well-being, including elevated self-worth and better emotional and behavioral control (Hayes and Feldman 2004; Keng et al. 2011; Rasmussen and Pidgeon 2011; Tanhan 2019, 2020). In this context, based on the current findings, it can be noted that both self-forgiveness and mindfulness have a healing effect on impacts of thwarted need satisfaction.

Empirical research already pointed out the functionality of self-forgiveness and mindfulness on psychological health and well-being like an enhanced positive development, better resilience, and coping in face of stressors, and decreased negative outcomes (Barnard and Curry 2011; Trompetter et al. 2017; Wohl et al. 2008). Compatible with this functionality, the present results demonstrated that self-forgiveness and mindfulness negatively predicted Internet addiction. In other words, participants with higher self-forgiveness and mindfulness levels reported lower Internet addiction, and they were influenced less by being socially excluded. Arslan (2017), for example, brought out that both forgiveness and mindfulness negatively predicted Internet addiction in young people. Specifically, mindfulness was found to be negatively related to addictive behaviors like Internet addiction (Calvete et al. 2017; GámezGuadix and Calvete 2016; Riley 2014). Moreover, not specific to Internet addiction, but several existing studies showed the benefits of self-forgiveness in coping with different addictive behaviors (Gueta 2013; Hook et al. 2015; Webb et al. 2011).

\section{Conclusions and Limitations}

The results from the current study should be considered in light of some limitations. First, the sample was formed based on a convenience sampling method, which decreases the representativeness of the sample. Secondly, it is a cross-sectional study with the use of self-report measurement tools that lacks cause and effect relationship. In that sense, replicating the hypotheses testing with different measurement approaches of experimental and longitudinal designs will boost the findings. Moreover, the current sample is also limited to university students, which limits the generalizability of the findings as well. Hence, testing the present variables with other age groups is recommended for further research. Finally, addressing other potential factors that mediate and moderate the effect of social exclusion on Internet addiction is needed to understand the nature of this relationship better.

In general, the present study brought to a conclusion that social exclusion has negative effects on Internet addiction in young adults, and self-forgiveness has meditated this association with the moderating role of mindfulness. This moderated mediation model suggests that mindfulness buffers the negative consequences of social exclusion that form a basis for problematic Internet use. First, mental health workers in the field are suggested to design prevention and intervention programs to deal with the problems brought by social exclusion like social anxiety, loneliness, social isolation, and impaired self-regulation (Baumeister and Leary 1995; Baumeister et al. 2005; Boardman 2011). These programs will overall contribute 
to psychological need satisfaction of belongingness for mental health and well-being with flourishing outcomes (Yıldırım and Çelik-Tanrıverdi 2020; Arslan 2018a; Arslan and Coşkun 2020; Duru and Arslan 2014). Negative outcomes caused by social exclusion (e.g., social anxiety and loneliness) are also some main determinants of Internet addiction as discussed throughout the current paper. Therefore, suggested interventions to professionals in the field may also contribute to the prevention of Internet addiction in youth.

Contending with negative outcomes of social exclusion and Internet addiction, mitigating and buffering roles of self-forgiveness and mindfulness should also be considered in intervention services. Mindfulness-based interventions were shown to be effective on broad content of problems (Shonin et al. 2013), as also for self-forgiveness-based intervention (Scherer et al. 2011). After all, the current study reached out that detrimental effects of social exclusion seem to hit Internet addiction as well, and promoting self-forgiveness and mindfulness in youth might be useful to help socially excluded and Internet-addicted individuals. In addition to all these, future researchers can utilize a quite new qualitative method called Online Photovoice (Doyumğaç et al. 2021; Tanhan et al. 2021) to understand the main variables in this study (e.g., social exclusion, Internet addiction) and the dynamic among them through mixed-method studies.

To conclude, self-forgiveness mediated the relationship between social exclusion and Internet addiction, and mindfulness moderated the mediating role of self-forgiveness. In other words, the results implied that mindfulness and self-forgiveness helped in dealing with social exclusion, so in return they may also help young adults lessen the risk for problematic Internet use. All these early findings mentioned above are supportive signs for generalizability of mitigating effects of self-forgiveness and mindfulness to social exclusion experience and Internet addiction. Hence, professionals in the field might take advantage of these buffering factors in their intervention programs against the effects of social exclusion and Internet addiction.

\section{Declarations}

Ethical Approval All procedures performed in studies involving human participants were in accordance with the ethical standards of the institutional and/or national research committee and with the 1964 Helsinki declaration and its later amendments or comparable ethical standards.

Informed Consent Consent was obtained from all participants included in the study.

Conflict of Interest The authors declare no competing interest.

\section{References}

Akdeniz, S., \& Deniz, M. (2016). Merhamet Ölçeği’nin Türkçeye uyarlanması: Geçerlik ve güvenirlik çalışması. The Journal of Happiness \& Well-Being, 4(1), 50-61.

Arslan, G. (2016). Relationship between sense of rejection, academic achievement, academic efficacy, and educational purpose in high school students. Education and Science, 41(183), 293-304.

Arslan, G. (2017). Psychological maltreatment, forgiveness, mindfulness, and Internet addiction among young adults: A study of mediation effect. Computers in Human Behavior, 72, 57-66. https://doi.org/10.1016/j. chb.2017.02.037.

Arslan, G. (2018a). School-based social exclusion, affective wellbeing, and mental health problems in adolescents: A study of mediator and moderator role of academic self-regulation. Child Indicators Research, 11(3), 963-980. https://doi.org/10.1007/s12187-017-9486-3. 
Arslan, G. (2018b). Social exclusion, social support and psychological wellbeing at school: A study of mediation and moderation effect. Child Indicators Research, 11(3), 897-918. https://doi.org/10.1007/s12187-0179451-1.

Arslan, G. (2018c). Psychological maltreatment, social acceptance, social connectedness, and subjective wellbeing in adolescents. Journal of Happiness Studies, 19(4), 983-1001.

Arslan, G. (2020). Loneliness, college belongingness, subjective vitality, and psychological adjustment during coronavirus pandemic: Development of the college belongingness questionnaire. Journal of Positive School Psychology. https://journalppw.com/index.php/JPPW/article/view/240.

Arslan, G. (2021). Social ostracism in school context: Academic self-Concept, prosocial behaviour, and conduct problems in adolescents. The Educational and Developmental Psychologist. https://doi.org/10.1080/ 20590776.2020 .1834830 .

Arslan, G., \& Coșkun, M. (2020). Student subjective wellbeing, school functioning, and psychological adjustment in high school adolescents: A latent variable analysis. Journal of Positive School Psychology, 4(2), 153-164. https://doi.org/10.47602/jpsp.

Arslan, G., Yıldırım, M., \& Zangeneh, M. (2021). Coronavirus anxiety and psychological adjustment in college students: Exploring the role of college belongingness and social media addiction. International Journal of Mental Health and Addiction. https://doi.org/10.1007/s11469-020-00460-4.

Bacon, A. K., Cranford, A. N., \& Blumenthal, H. (2015). Effects of ostracism and sex on alcohol consumption in a clinical laboratory setting. Psychology of Addictive Behaviors, 29(3), 664-672. https://doi.org/10.1037/ adb0000054.

Bagir, A., Emre, O., Cumurcu, H. B., \& Ulutas, A. (2020). The relationship between social exclusion (ostracism) and Internet addiction of adolescent girls. Research in Pedagogy, 10(1), 50-65.

Barnard, L. K., \& Curry, J. F. (2011). Self-compassion: Conceptualizations, correlates, \& interventions. Review of General Psychology, 15(4), 289-303. https://doi.org/10.1037/a0025754.

Bastian, B., \& Haslam, N. (2010). Excluded from humanity: The dehumanizing effects of social ostracism. Journal of Experimental Social Psychology, 46(1), 107-113. https://doi.org/10.1016/j.jesp.2009.06.022.

Baumeister, R. F. (2012). Need-to-belong theory. In P. A. M. Van Lange, A. W. Kruglanski, \& E. T. Higgins (Eds.), Handbook of theories of social psychology (pp. 121-140). London: Sage Publications Ltd..

Baumeister, R. F., \& Leary, M. R. (1995). The need to belong: Desire for interpersonal attachments as a fundamental human motivation. Psychological Bulletin, 117(3), 497-529. https://doi.org/10.1037/00332909.117.3.497.

Baumeister, R. F., DeWall, C. N., Ciarocco, N. J., \& Twenge, J. M. (2005). Social exclusion impairs selfregulation. Journal of Personality and Social Psychology, 88(4), 589-604. https://doi.org/10.1037/00223514.88.4.589.

Boardman, J. (2011). Social exclusion and mental health-how people with mental health problems are disadvantaged: An overview. Mental Health and Social Inclusion, 15(3), 112-121. https://doi.org/10.1108/ 20428301111165690.

Boysan, M., Kuss, D. J., Barut, Y., Ayköse, N., Güleç, M., \& Özdemir, O. (2017). Psychometric properties of the Turkish version of the Internet Addiction Test (IAT). Addictive Behaviors, 64, 247-252. https://doi.org/10. 1016/j.addbeh.2015.09.002.

Bozoglan, B., \& Demirer, V. (2015). The association between Internet addiction and psycho-social variables. In J. Bishop (Ed.), Psychological and social issues surrounding Internet and gaming addiction (p. 171e185). Hershey, PA: IGI Global.

Buelow, M. T., \& Wirth, J. H. (2017). Decisions in the face of known risks: Ostracism increases risky decisionmaking. Journal of Experimental Social Psychology, 69, 210-217. https://doi.org/10.1016/j.jesp.2016.07. 006.

Bugay, A., \& Demir, A. (2010). A Turkish version of heartland forgiveness scale. Procedia-Social and Behavioral Sciences, 5, 1927-1931. https://doi.org/10.1016/j.sbspro.2010.07.390.

Calvete, E., Gámez-Guadix, M., \& Cortazar, N. (2017). Mindfulness facets and problematic Internet use: A sixmonth longitudinal study. Addictive Behaviors, 72, 57-63. https://doi.org/10.1016/j.addbeh.2017.03.018.

Caplan, S. E. (2007). Relations among loneliness, social anxiety, and problematic Internet use. Cyberpsychology \& Behavior, 10(2), 234-242. https://doi.org/10.1089/cpb.2006.9963.

Caplan, S. E. (2010). Theory and measurement of generalized problematic Internet use: A two-step approach. Computers in Human Behavior, 26(5), 1089-1097. https://doi.org/10.1016/j.chb.2010.03.012.

Christensen-Salem, A., Walumbwa, F. O., Babalola, M. T., Guo, L., \& Misati, E. (2020). A multilevel analysis of the relationship between ethical leadership and ostracism: The roles of relational climate, employee mindfulness, and work unit structure. Journal of Business Ethics, 1-20. https://doi.org/10.1007/s10551020-04424-5.

Deci, E. L., \& Ryan, R. M. (1985). Intrinsic motivation and self-determination in human behavior. New York: Plenum. 
Deci, E. L., \& Ryan, R. M. (2008). Self-determination theory: A macrotheory of human motivation, development, and health. Canadian Psychology, 49(3), 182-185. https://doi.org/10.1037/a0012801.

Donne, J. (1975). Devotions upon emergent occasions. Oxford University Press.

Doyumğaç, İ., Tanhan, A., \& Kıymaz, M. S. (2021). Understanding the most important facilitators and barriers for online education during COVID-19 through online photovoice methodology. International Journal of Higher Education, 10(1), 166-190. https://doi.org/10.5430/ijhe.v10n1p166.

Duru, E. (2015). Genel Aidiyet Ö98lçeğinin psikometrik özellikleri: Geçerlik ve güvenirlik çalıșması. Türk Psikolojik Danışma ve Rehberlik Dergisi, 5(44), 37-47.

Duru, E., \& Arslan, G. (2014). Evlenmek amacıyla evden kaçan kız ergenler: Bir olgubilim çalıșması[Girl adolescents who run away from home to get married: A phenomenological study]. Türk Psikolojik Danışma ve Rehberlik Dergisi, 5(41), 36-48.

Duru, E., Arslan, G., \& Balkıs, M. (2016). Social exclusion, resilience, negative self-concept, and problem behaviors in adolescents [Ergenlerde sosyal dișlanma, psikolojik sağlamlık, olumsuz benlik algısı ve problem davranışlar]. IIIrd International Eurasian Educational Research Congress, 31 May-3 Jun, Muğla, Turkiye.

Egan, L. A., \& Todorov, N. (2009). Forgiveness as a coping strategy to allow school students to deal with the effects of being bullied: Theoretical and empirical discussion. Journal of Social and Clinical Psychology, 28(2), 198-222. https://doi.org/10.1521/jscp.2009.28.2.198.

Field, A. (2009). Discovering statistics using SPSS. Sage publications.

Florez, E., Cohen, K., Ferenczi, N., Linnell, K., Lloyd, J., Goddard, L., Kumashiro, M., \& Freeman, J. (2020). Linking recent discrimination-related experiences and wellbeing via social cohesion and resilience. Journal of Positive School Psychology, 4(1-Sup1), 92-104.

Fung, K., Xu, C., Glazier, B. L., Parson, A., \& Alden, L. E. (2016). Research in clinical psychology: Social exclusion and psychological disorders. In P. Riva \& J. Eck (Eds.), Social exclusion: Psychological approaches to understanding and reducing its impact (pp. 157-176). Heidelberg: Springer.

Gámez-Guadix, M., \& Calvete, E. (2016). Assessing the relationship between mindful awareness and problematic Internet use among adolescents. Mindfulness, 7(6), 1281-1288. https://doi.org/10.1007/s12671-0160566-0.

Gilman, R., Carter-Sowell, A., DeWall, C. N., Adams, R. E., \& Carboni, I. (2013). Validation of the ostracism experience scale for adolescents. Psychological Assessment, 25(2), 319-330. https://doi.org/10.1037/ a0030913.

Gueta, K. (2013). Self-forgiveness in the recovery of Israeli drug-addicted mothers: A qualitative exploration. Journal of Drug Issues, 43(4), 450-467. https://doi.org/10.1177/0022042613491097.

Hall, J. H., \& Fincham, F. D. (2005). Self-forgiveness: The stepchild of forgiveness research. Journal of Social and Clinical Psychology, 24(5), 621-637. https://doi.org/10.1521/jscp.2005.24.5.621.

Hartgerink, C. H., Van Beest, I., Wicherts, J. M., \& Williams, K. D. (2015). The ordinal effects of ostracism: A meta-analysis of 120 Cyberball studies. PLoS One, 10(5), e0127002. https://doi.org/10.1371/journal.pone. 0127002 .

Hayes, A. F. (2018). Introduction to mediation, moderation, and conditional process analysis: A regressionbased approach. Guilford Press.

Hayes, A. M., \& Feldman, G. (2004). Clarifying the construct of mindfulness in the context of emotion regulation and the process of change in therapy. Clinical Psychology: Science and Practice, 11(3), 255262. https://doi.org/10.1093/clipsy.bph080.

Heppner, W. L., Kernis, M. H., Lakey, C. E., Campbell, W. K., Goldman, B. M., Davis, P. J., \& Cascio, E. V. (2008). Mindfulness as a means of reducing aggressive behavior: Dispositional and situational evidence. Aggressive Behavior: Official Journal of the International Society for Research on Aggression, 34(5), 486496. https://doi.org/10.1002/ab.20258.

Hook, J. N., Farrell, J. E., Davis, D. E., Van Tongeren, D. R., Griffin, B. J., Grubbs, J., et al. (2015). Selfforgiveness and hypersexual behavior. Sexual Addiction \& Compulsivity, 22(1), 59-70. https://doi.org/10. 1080/10720162.2014.1001542.

Jahanzeb, S., Fatima, T., Javed, B., \& Giles, J. P. (2020). Can mindfulness overcome the effects of workplace ostracism on job performance? The Journal of Social Psychology, 160(5), 1-14. https://doi.org/10.1080/ 00224545.2019 .1707465 .

Jiang, T., \& Chen, Z. (2020). Meaning in life accounts for the association between long-term ostracism and depressive symptoms: The moderating role of self-compassion. The Journal of Social Psychology, 160(5), 535-547. https://doi.org/10.1080/00224545.2019.1693951. 
Keng, S. L., Smoski, M. J., \& Robins, C. J. (2011). Effects of mindfulness on psychological health: A review of empirical studies. Clinical Psychology Review, 31(6), 1041-1056. https://doi.org/10.1016/j.cpr.2011.04.006.

Koç, P. (2017). Internet addiction and subjective well-being in university students. Journal of Positive School Psychology, 1(1), 34-41.

LaRose, R., Lin, C. A., \& Eastin, M. S. (2003). Unregulated internet usage: Addiction, habit, or deficient selfregulation? Media Psychology, 5(3), 225-253. https://doi.org/10.1207/S1532785XMEP0503_01.

Lim, M. (2019). Social exclusion, surveillance use, and Facebook addiction: The moderating role of narcissistic grandiosity. International Journal of Environmental Research and Public Health, 16(20), 3813. https://oi. org/10.3390/ijerph16203813.

Lundwall, C., Fairborn, S., Quinones-Camacho, L., Estep, J., \& Davis, E. (2019). Self-regulation mechanisms explain how dispositional mindfulness promotes well-being. Journal of Positive School Psychology, 3(2), $153-164$.

Malone, G. P., Pillow, D. R., \& Osman, A. (2012). The general belongingness scale (GBS): Assessing achieved belongingness. Personality and Individual Differences, 52(3), 311-316.

Molden, D. C., Lucas, G. M., Gardner, W. L., Dean, K., \& Knowles, M. L. (2009). Motivations for prevention or promotion following social exclusion: Being rejected versus being ignored. Journal of Personality and Social Psychology, 96(2), 415-431. https://doi.org/10.1037/a0012958.

Oaten, M., Williams, K. D., Jones, A., \& Zadro, L. (2008). The effects of ostracism on self-regulation in the socially anxious. Journal of Social and Clinical Psychology, 27(5), 471-504. https://doi.org/10.1521/jscp. 2008.27.5.471.

Özdemir, Y., Kuzucu, Y., \& Ak, Ș. (2014). Depression, loneliness, and Internet addiction: How important is low self-control? Computers in Human Behavior, 34, 284-290. https://doi.org/10.1016/j.chb.2014. 02.009 .

Peake, S. J., Dishion, T. J., Stormshak, E. A., Moore, W. E., \& Pfeifer, J. H. (2013). Risk-taking and social exclusion in adolescence: Neural mechanisms underlying peer influences on decision-making. NeuroImage, 82, 23-34. https://doi.org/10.1016/j.neuroimage.2013.05.061.

Pezoa-Jares, R. E., Espinoza-Luna, I. L., \& Vasquez-Medina, J. A. (2012). Internet addiction: A review. Journal of Addiction Research \& Therapy, S6. https://doi.org/10.4172/2155-6105.S6-004.

Pfundmair, M., Graupmann, V., Frey, D., \& Aydin, N. (2015). The different behavioral intentions of collectivists and individualists in response to social exclusion. Personality and Social Psychology Bulletin, 41(3), 363378. https://doi.org/10.1177/0146167214566186.

Pommier, E. A. (2011). The compassion scale. Dissertation Abstracts International Section A: Humanities and Social Sciences, 72(4-A), 1174.

Poon, K. T. (2018). Unpacking the mechanisms underlying the relation between ostracism and Internet addiction. Psychiatry Research, 270, 724-730. https://doi.org/10.1016/j.psychres.2018.10.056.

Preacher, K. J., \& Hayes, A. F. (2008). Asymptotic and resampling strategies for assessing and comparing indirect effects in multiple mediator models. Behavior Research Methods, 40(3), 879-891. https://doi.org/ 10.3758/BRM.40.3.879.

Rasmussen, M. K., \& Pidgeon, A. M. (2011). The direct and indirect benefits of dispositional mindfulness on self-esteem and social anxiety. Anxiety, Stress, \& Coping, 24(2), 227-233. https://doi.org/10.1080/ 10615806.2010.515681.

Ren, D., Wesselmann, E., \& Williams, K. D. (2016). Evidence for another response to ostracism: Solitude seeking. Social Psychological and Personality Science, 7(3), 204-212. https://doi.org/10.1177/ 1948550615616169.

Riley, B. (2014). Experiential avoidance mediates the association between thought suppression and mindfulness with problem gambling. Journal of Gambling Studies, 30(1), 163-171. https://doi.org/10.1007/s10899-0129342-9.

Riva, P., Wirth, J. H., \& Williams, K. D. (2011). The consequences of pain: The social and physical pain overlap on psychological responses. European Journal of Social Psychology, 41(6), 681-687. https://doi.org/10. $1002 /$ ejsp.837.

Scherer, M., Worthington Jr., E. L., Hook, J. N., \& Campana, K. L. (2011). Forgiveness and the bottle: Promoting self-forgiveness in individuals who abuse alcohol. Journal of Addictive Diseases, 30(4), 382395. https://doi.org/10.1080/10550887.2011.609804.

Shonin, E., Van Gordon, W., \& Griffiths, M. (2013). Mindfulness-based interventions: Towards mindful clinical integration. Frontiers in Psychology, 4, 194. https://doi.org/10.3389/fpsyg.2013.00194.

Sjåstad, H., Zhang, M., Masvie, A. E., \& Baumeister, R. (2020). Social exclusion reduces happiness by creating expectations of future rejection. Self and Identity, 20, 1-10. https://doi.org/10.1080/15298868.2020. 1779119. 
Stanley, P. J., Schutte, N. S., \& Phillips, W. J. (2020). A meta-analytic investigation of the relationship between basic psychological need satisfaction and affect. Journal of Positive School Psychology, 1-16.

Stillman, T. F., Baumeister, R. F., Lambert, N. M., Crescioni, A. W., DeWall, C. N., \& Fincham, F. D. (2009). Alone and without purpose: Life loses meaning following social exclusion. Journal of Experimental Social Psychology, 45(4), 686-694. https://doi.org/10.1016/j.jesp.2009.03.007.

Tanhan, A. (2019). Acceptance and commitment therapy with ecological systems theory: Addressing Muslim mental health issues and wellbeing. Journal of Positive Psychology and Wellbeing, 3(2), 197-219. https:// doi.org/10.47602/jpsp.v3i2.172.

Tanhan, A. (2020). COVID-19 sürecinde online seslifoto (OSF) yöntemiyle biyopsikososyal manevi ve ekonomik meseleleri ve genel iyi oluș düzeyini ele almak: OSF'nin Türkçeye uyarlanması. [Utilizing online photovoice (OPV) methodology to address biopsychosocial spiritual economic issues and wellbeing during COVID-19: Adapting OPV to Turkish.]. Turkish Studies, 15(4), 1029-1086. https://doi.org/10.7827/ TurkishStudies.44451.

Tanhan, A., \& Francisco, V. T. (2019). Muslims and mental health concerns: A social ecological model perspective. Journal of Community Psychology, 47(4), 964-978 https://onlinelibrary.wiley.com/doi/full/10. 1002/jcop. 22166 .

Tanhan, A., \& Strack, R. W. (2020). Online photovoice to explore and advocate for Muslim biopsychosocial spiritual wellbeing and issues: Ecological systems theory and ally development. Current Psychology, 39(6), 2010-2025. https://doi.org/10.1007/s12144-020-00692-6.

Tanhan, A., Arslan, G., Yavuz, K. F., Young, J. C., Çiçek, İ., Akkurt, M. N., Ulus, İ. Ç., Görünmek, E. T., Demir, R., Kürker, F., Çelik, C., Akça, M. Ș., Ünverdi, B., Ertürk, H. (2021). A constructive understanding of mental health facilitators and barriers through Online Photovoice (OPV) during COVID-19. Manuscript under review.

Tas, B., \& Öztosun, A. (2018). Predictability of Internet addiction with adolescent perception of social support and ostracism experiences. Turkish Online Journal of Educational Technology-TOJET, 17(4), 32-41.

Thompson, L. Y., Snyder, C. R., Hoffman, L., Michael, S. T., Rasmussen, H. N., Billings, L. S., ... \& Roberts, D. E. (2005). Dispositional forgiveness of self, others, and situations. Journal of Personality, 73(2), 313-360. https://doi.org/10.1111/j.1467-494.2005.00311.x.

Tokunaga, R. S. (2015). Perspectives on Internet addiction, problematic Internet use, and deficient self-regulation: Contributions of communication research. Annals of the International Communication Association, 39(1), 131-161. https://doi.org/10.1080/23808985.2015.11679174.

Trompetter, H. R., de Kleine, E., \& Bohlmeijer, E. T. (2017). Why does positive mental health buffer against psychopathology? An exploratory study on self-compassion as a resilience mechanism and adaptive emotion regulation strategy. Cognitive Therapy and Research, 41(3), 459-468. https://doi.org/10.1007/s10608-0169774-0.

Twenge, J. M., Catanese, K. R., \& Baumeister, R. F. (2002). Social exclusion causes self-defeating behavior. Journal of Personality and Social Psychology, 83(3), 606-615. https://doi.org/10.1037/0022-3514.83.3.606.

Wang, Z., Tchernev, J. M., \& Solloway, T. (2012). A dynamic longitudinal examination of social media use, needs, and gratifications among college students. Computers in Human Behavior, 28(5), 1829-1839. https:// doi.org/10.1016/j.chb.2012.05.001.

Webb, J. R., Robinson, E. A., \& Brower, K. J. (2011). Mental health, not social support, mediates the forgiveness-alcohol outcome relationship. Psychology of Addictive Behaviors, 25(3), 462-473. https://doi. org/10.1037/a0022502.

Williams, K. D. (2007a). Ostracism. Annual Review of Psychology, 58, 425-452. https://doi.org/10.1146/ annurev.psych.58.110405.085641.

Williams, K. D. (2007b). Ostracism: The kiss of social death. Social and Personality Compass, 1(1), 236-247. https://doi.org/10.1111/j.1751-9004.2007.00004.x.

Wohl, M. J., \& McLaughlin, K. J. (2014). Self-forgiveness: The good, the bad, and the ugly. Social and Personality Psychology Compass, 8(8), 422-435. https://doi.org/10.1111/spc3.12119.

Wohl, M. J. A., DeShea, L., \& Wahkinney, R. L. (2008). Looking within: Measuring state self-forgiveness and its relationship to psychological well-being. Canadian Journal of Behavioral Science, 40(1), 1-10. https:// doi.org/10.1037/0008-400x.40.1.1.1.

Yao, M. Z., \& Zhong, Z. (2014). Loneliness, social contact and Internet addiction: A cross-lagged panel study. Computers in Human Behavior, 30, 164-170. https://doi.org/10.1016/j.chb.2013.08.007.

Yıldırım, M., \& Çelik-Tanrıverdi, F. (2020). Social support, resilience and subjective well-being in college students. Journal of Positive School Psychology. https://journalppw.com/index.php/JPPW/article/view/229.

Young, K. S. (1998). Caught in the net: How to recognize the signs of internet addiction-and a winning strategy for recovery. Hoboken, NJ: John Wiley \& Sons. 
Young, K. S., Yue, X. D., \& Ying, L. (2011). Prevalence estimates and etiologic models of Internet addiction. In K. S. Young \& C. N. de Abreu (Eds.), Internet addiction: A handbook and guide to evaluation and treatment (p. 3e18). Hoboken, NJ: John Wiley \& Sons.

Zhang, D., Li, S., Shao, L., Hales, A. H., Williams, K. D., \& Teng, F. (2019). Ostracism increases automatic aggression: The role of anger and forgiveness. Frontiers in Psychology, 10, 2659. https://doi.org/10.3389/ fpsyg.2019.02659.

Publisher's Note Springer Nature remains neutral with regard to jurisdictional claims in published maps and institutional affiliations. 